\title{
Bcl-2 Sustains Increased Mucous and Epithelial Cell Numbers in Metaplastic Airway Epithelium
}

\author{
J. Foster Harris, Mark J. Fischer, Jon R. Hotchkiss, Brett P. Monia, Scott H. Randell, Jack R. Harkema, \\ and Yohannes Tesfaigzi
}

Lovelace Respiratory Research Institute, Albuquerque, New Mexico; Dow Chemical Company, Midland; Department of Pathobiology and Diagnostic Investigation, Michigan State University, East Lansing, Michigan; Cystic Fibrosis/Pulmonary Research and Treatment Center, University of North Carolina, Chapel Hill, North Carolina; ISIS Pharmaceuticals, Department of Molecular Pharmacology, Carlsbad, California

Bcl-2, an inhibitor of apoptosis, is expressed in LPS-induced metaplastic goblet cells of rat airways. The present study investigated expression of $\mathrm{Bcl}-2$ in airway mucous cells of persons with cystic fibrosis and tested in rats and mice whether its expression is responsible for sustaining metaplastic mucous cells. A significantly higher percentage of mucous cells expressed $\mathrm{Bcl}-2$ in humans with cystic fibrosis compared with control subjects with no disease or subjects with other diseases. In LPS-instilled F344/N rats, the percentage of $\mathrm{BCl}-2-$ positive mucous cells was decreased to background levels before the resolution of goblet cell metaplasia. Furthermore, intraperitoneal injection of rats with antisense oligonucleotides significantly reduced $\mathrm{Bcl}-2$ expression and goblet cell metaplasia in nasal and pulmonary airway epithelia in rats. In contrast, sustained expression of $\mathrm{BCl}-2$ in transgenic mice by a metallothionein promoter caused increased LPS-induced goblet cell metaplasia over 8 days compared with wild-type mice. These studies demonstrate that $\mathrm{Bcl}-2$ expression sustains goblet cell metaplasia in various species, that epithelial cell numbers are directly linked to the regulation of the numbers of goblet cells, and that downregulating Bcl-2 expression reduces goblet cell metaplasia.

Keywords: apoptosis; antisense oligonucleotides; cystic fibrosis; inflammation; LPS

One of the main reasons for the morbidity of patients with chronic pulmonary diseases, such as cystic fibrosis (CF) and asthma, is increased mucous secretions causing airway obstruction. Reduction of mucous secretions in CF is of great interest, because intervention strategies by gene therapy approaches to replace the CFTR gene or by reducing inflammation have largely been unsuccessful.

Inflammatory responses recruit nonciliated columnar epithelial cells into the cell cycle in large numbers (1) and thereby increase the number of cells per millimeter of basal lamina (BL) (2). This increase is accompanied by the appearance of mucusproducing cells in areas normally devoid of these cells and is called goblet cell metaplasia (GCM) (3). GCM allows the epithelium to produce larger amounts of mucus, because both preexisting and proliferating cells synthesize mucus (2). The generation of metaplastic mucous cells and the mechanisms by which inflammatory mediators induce the synthesis of mucus and the differentiation of surface epithelial cells into mucus-producing cells have been

(Received in original form August 24, 2004; accepted in final form December 9, 2004) Supported, in part, by grants from the National Institutes of Environmental Health Sciences (ES09237) and the National Heart, Lung, and Blood Institute (HL68111).

Correspondence and requests for reprints should be addressed to Yohannes Tesfaigzi, Ph.D., Lovelace Respiratory Research Institute, 2425 Ridgecrest Drive, SE, Albuquerque, NM 87108. E-mail: ytesfaig@|rri.org

This article has an online supplement, which is accessible from this issue's table of contents at www.atsjournals.org

Am J Respir Crit Care Med Vol 171. pp 764-772, 2005

Originally Published in Press as DOI: 10.1164/rccm.200408-11080C on December 23, 2004

Internet address: www.atsjournals.org extensively studied. In contrast, mediators involved in reducing the numbers of metaplastic mucous cells after inflammatory responses subside are not well understood.

In an attempt to understand mechanisms that reduce numbers of metaplastic mucous cells during the resolution of inflammatory responses, we discovered that metaplastic mucous cells express regulators of apoptosis from the Bcl-2 family of proteins (4-6). Exposure of rats to LPS or allergen causes airway epithelial cells to proliferate, and nonproliferating and proliferating cells differentiate into mucous cells to establish GCM (2). Approximately 20 to $30 \%$ of the developing metaplastic mucous cells express Bcl-2 (5). Furthermore, exposure of rats to ozone induces GCM in nasal epithelia and Bcl-2 is expressed in epithelia where GCM occurs (4).

The Bcl-2 family of cytoplasmic proteins can register diverse forms of intracellular damage, gauge whether other cells have provided a positive or negative death stimulus, and determine the progression or inhibition of the suicide program (7). Bcl-2, an inhibitor of apoptosis, is a member of a large group of regulatory proteins that prevent or induce apoptosis. The activation of proapoptotic signals leads to inactivation of Bcl-2 by Bcl-2 homology region-3 domain-only family members and triggers $\mathrm{Bax}$ or Bak to permeabilize mitochondria to release cytochrome $\mathrm{c}$, which initiates the activation of caspases and DNases responsible for the appearance of the apoptotic morphology (8-10). This morphology includes DNA fragmentation, chromatin condensation, membrane blebbing, cell shrinkage, and disassembly of the cell (10).

The present study tested the hypothesis that disruption of mechanisms to resolve GCM could account for sustained GCM in $\mathrm{CF}$ where mucous hypersecretion reduces airflow. Our findings suggest that $\mathrm{Bcl}-2$ plays a central role in the resolution of GCM and may be a useful target for reducing mucus-secreting cells in chronic diseases. Some results from these studies have been previously reported in the form of an abstract (11).

\section{METHODS}

See the online supplement for additional details regarding laboratory animals, in situ hybridization, microdissection of airway epithelia, polymerase chain reaction, and Western blot analyses.

\section{Tissues from Human Subjects}

Paraffin-embedded lung tissues with small airways were obtained under the auspices of the University of North Carolina and the Lovelace Respiratory Research Institute institutional review boards' approved protocols. Tissue sections $(5-\mu \mathrm{m}$ thick) originated from 14 subjects without lung diseases, 8 subjects with $\mathrm{CF}$, and 8 subjects with diseases such as interstitial pulmonary fibrosis, pulmonary hypertension, and $\alpha 1$-antitrypsin (Table 1). All histology sections represent sections of airways and lungs excised during transplantation for end-stage lung disease or excess portions of donors.

\section{Laboratory Animals}

Male F344/N rats (8-10 weeks old) were purchased from Frederick Cancer Research, Frederick, MD. Bcl-2 transgenic mice on a C57B1/6 background 
TABLE 1. DEMOGRAPHICS OF AIRWAY TISSUE DONORS

\begin{tabular}{lccc}
\hline & Normal $(n=14)$ & CF $(n=8)$ & Other $(n=8)$ \\
\hline Mean age, yr & 43 & 27 & 46 \\
Sex & $9 \mathrm{M}, 5 \mathrm{~F}$ & $7 \mathrm{M}, 1 \mathrm{~F}$ & $5 \mathrm{M}, 3 \mathrm{~F}$ \\
Diagnosis & & $2 \mathrm{M}, 1 \mathrm{~F} \mathrm{DF} / \mathrm{DF}$ & $2 \mathrm{M} \mathrm{IPF}$ \\
& $1 \mathrm{M} \mathrm{DF} / \mathrm{G} 551 \mathrm{D}$ & $1 \mathrm{M}, 1 \mathrm{~F} \mathrm{PHTN}$ \\
& $1 \mathrm{~F} \mathrm{DF} / 621+1 \mathrm{G}>\mathrm{T}$ & $1 \mathrm{M} \alpha 1-\mathrm{AT}$ \\
& & $1 \mathrm{M} \mathrm{COPD}, 2 \mathrm{~F}$ non-CF bronchiectasis
\end{tabular}

Definition of abbreviations: $\alpha 1$-AT $=\alpha 1$-antitrypsin; $\mathrm{CF}=$ cystic fibrosis; COPD = chronic pulmonary obstructive disease; DF $=$ deletion of phenylalanine; $\mathrm{F}=$ female; $\mathrm{G}>\mathrm{T}=$ transversion mutations; IPF = interstitial pulmonary fibrosis; $\mathrm{M}=$ male; $\mathrm{PHTN}=$ pulmonary hypertension.

with the Bcl-2 transgene under the control of the mouse metallothionein promoter (provided by Dr. Nelson Fausto, University of Washington, Seattle, WA) were bred at the Lovelace Respiratory Research Institute. Instillation for rats and mice was as described $(12,13)$. All experiments were approved by the Institutional Animal Care and Use Committee and were performed at the Lovelace Respiratory Research Institute, a facility approved by the Association for the Assessment and Accreditation for Laboratory Animal Care International.

\section{Rat Nasal Explant Cultures and Treatment with Antisense Oligonucleotides}

Nasal explants were treated with $100 \mu \mathrm{g} / \mathrm{ml}$ endotoxin in medium ( $\mathrm{n}=4$ /group) for 24 hours and maintained in culture in endotoxinfree medium for 2 additional days. They were then fixed in zinc formalin and processed for histologic analyses as described (14). They were treated with $30 \mu \mathrm{M}$ antisense oligonucleotides (ASODNs) in $40 \mu \mathrm{l}$ culture medium and $3 \mu$ lipofectamine (Life Technologies, San Diego, CA). Table 2 shows the sequences of the ASODNs and control ODNs, which were 2-O-methoxy ethyl thioate derivatives (15).

TABLE 2. SEQUENCES OF THE ANTISENSE OLIGONUCLEOTIDES AND THEIR POSITION WITHIN THE BCl-2 mRNA

\begin{tabular}{|c|c|c|c|}
\hline ASODN No. & mRNA Region & Base Position & Sequence \\
\hline 101160 & 5' UTR & 1 & САGCTTTTTATTTCATGAGG \\
\hline 101161 & & 39 & TGGCATGAGATGCAGGAAAT \\
\hline 101162 & & 75 & AGTTATGACGAACACTTGAT \\
\hline 101163 & & 110 & ATGTGCTTTGCATTCTTGGA \\
\hline 101164 & & 181 & АСТTCGСGTСССGGCTCCCG \\
\hline 101165 & & 205 & AAAGAAGCTGCAGGTACCAA \\
\hline 101166 & Coding R & 221 & CGCCATCCTTCCGGGGAAAG \\
\hline 101167 & & 241 & TACCCTGTTCTCCCGGCTTG \\
\hline 101168 & & 255 & ТСTCCCGGTTATCATACCCT \\
\hline 101169 & & 265 & TTCATCACGATCTCCCGGTT \\
\hline 101170 & & 270 & TGTACTTCATCACGATCTCC \\
\hline 101171 & & 295 & ССССТСТGTGAСАGСТTАТА \\
\hline 101172 & & 301 & TCGTAGCCССТСTGTGACAG \\
\hline 101173 & & 321 & СТTCATCTCCAGTATCCCAC \\
\hline 101174 & & 370 & TGGAAGGAGAAGATGCCAGG \\
\hline 101175 & & 390 & GCGTTCGGTTGCTCTCAGGC \\
\hline 101176 & & 421 & GTCCTGGCAGCCGTGTCTCG \\
\hline 101177 & & 541 & AAGTCGCGACGGTAGCGACG \\
\hline 101178 & & 671 & CССACCGAACTCAAAGAAGG \\
\hline 101179 & & 675 & TGACCCCACCGAACTCAAAG \\
\hline 101180 & & 781 & TTATCCTGGATCCAGGTGTG \\
\hline 101181 & & 850 & AGCCAGGAGAAATCAAACAG \\
\hline 101182 & & 911 & GTATGCACCCAGAGTGATGC \\
\hline 101183 & & 971 & СTTTAGTGAACCTTTTCATA \\
\hline 101184 & $3^{\prime}$ UTR & 1021 & ACAACTTTGTTTCATGGTCC \\
\hline
\end{tabular}

Definition of abbreviations: ASODN = antisense oligonucleotide; UTR = untranslated region.

\section{Injection of Rats with ASODN and LPS Instillations}

Rats were injected intraperitoneally with $0.5 \mu \mathrm{l}$ saline, control ODN, or ASODNs two times a day at $5 \mathrm{mg} / \mathrm{kg}$ in saline for 10 consecutive days. On Day 7 or 8 of injection, rats were intratracheally instilled with $1 \mathrm{mg}$ LPS in $0.5 \mathrm{ml}$ saline or intranasally instilled with $100 \mu \mathrm{l} /$ naris of $1 \mathrm{mg} / \mathrm{ml}$ LPS and killed 72 or 48 hours later, respectively.

\section{Histochemical Staining, Quantification, In Situ Hybridization, Real-Time Polymerase Chain Reaction, and Western Blot Analysis}

Tissue blocks that corresponded to the same nasal anatomic site examined in the in vitro experiments described previously and intrapulmonary airways of the left lung lobes were obtained as described (16). Staining and quantification of mucous cell numbers and intraepithelial stored mucosubstances were performed as described (17-19). Bcl-2 was detected by immunohistochemistry using two different Bcl-2 antibodies (BD-Pharmingen, San Diego, CA, or Santa Cruz Biotechnology, Santa Cruz, CA) at a dilution of 1:1000 or 1:50, respectively, as described (12). In situ hybridizations, real-time polymerase chain reaction, and Western blot analyses were performed as described previously (20-22). See the online supplement for a detailed method description and regarding RNA isolation and polymerase chain reaction.

\section{Statistical Analysis of Data}

Data were expressed as the mean group value $\pm \mathrm{SE}$ of the mean. Differences among groups were examined by analysis of variance and $t$ tests using SAS software (Cary, NC) and by application of Bonferonni correction for multiple comparisons. Group means were considered significantly different when $\mathrm{p}$ values were 0.05 or less.

\section{RESULTS}

\section{Bcl-2 Expression in Mucous Cells from Subjects with CF}

We have previously reported that Bcl-2 is expressed in metaplastic mucous cells of rats exposed to ozone, cigarette smoke (4), or LPS (5). To further study the relevance of Bcl-2 expression in human chronic disease, we analyzed lung tissues that were obtained from individuals with no disease and from individuals who have $\mathrm{CF}$, pulmonary hypertension, or bronchiectasis. Lungs from patients with $\mathrm{CF}$ were chosen because infections with gramnegative bacteria are common in these patients and may resemble the response we see in the rat lung after instillation of LPS (5). Although an average of 1 to $2 \%$ of mucous cells were Bcl-2-positive in airways from normal subjects or from subjects with other lung diseases, such as pulmonary hypertension and bronchiectasis, an average of $8 \%$ of mucous cells in lung epithelia of patients with $\mathrm{CF}$ showed immunostaining for Bcl-2 (Figures 1A and 1B). We noticed heterogeneity in Bcl-2 positivity of mucous cells in some tissue sections from subjects with CF. In some airways, up to $40 \%$ of goblet cells expressed Bcl-2, whereas in adjacent airways, only 1 to $2 \%$ of goblet cells were Bcl-2-positive. The identity of Bcl-2 was further verified by in situ hybridization, which showed a strong signal in epithelia where $\mathrm{Bcl}-2$ was detected by 
A
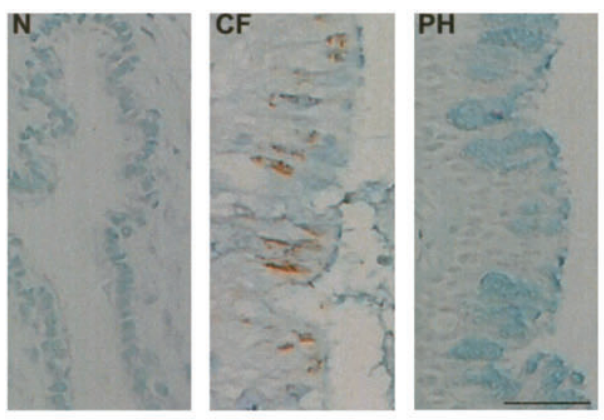

B

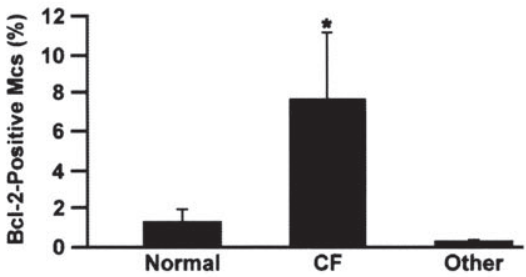

C
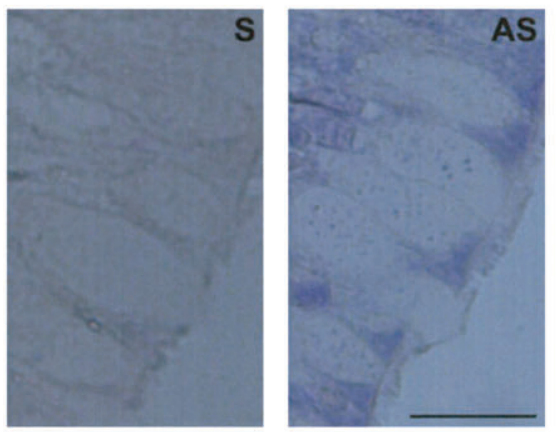

D

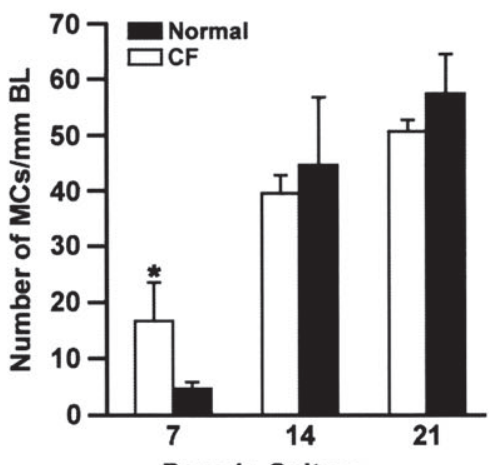

Days in Culture
Figure 1. Increased percentages of mucous cells are Bcl-2-positive in airways of patients with cystic fibrosis (CF) compared with airways from subjects who have other lung diseases than CF or control subjects with no disease. Tissue sections were immunostained for $\mathrm{BCl}-2$ as described in Methods. Nuclei and intraepithelial mucosubstances stain blue, and $\mathrm{BCl}-2$ immunostaining was detected with diaminobenzidine and shows brown. $(A)$ The percentage of $\mathrm{BCl}$-2-positive mucous cells (MCs) was quantified by enumerating the number of Alcian blue (AB-)-positive MCs and the MCs that had immunostained with the $\mathrm{Bcl}-2$ antibody (BD-Pharmingen). Bar represents $20 \mu \mathrm{m} . \mathrm{N}=$ normal; $\mathrm{PH}=$ pulmonary hypertension. (B) At least $250 \mathrm{AB}$-positive cells were counted to determine the percentage of positive $\mathrm{BCl}-2 \mathrm{MCs}$. Values are group means \pm SEM; $\mathrm{n}=7$ to 10 subjects/group. *Significantly different from control subjects with no disease, $p<0.05$. (C) In situ hybridization of tissue sections from a subject with CF with antisense (AS) and sense (S) CRNA probes to Bcl-2. Bar represents $10 \mu \mathrm{m}$. $(D)$ Increase in MCs per millimeter of basal lamina (BL) in well differentiated cultures of primary airway epithelial cells from three subjects without lung disease and three subjects with CF. * ${ }^{*}$ ignificantly different from control subjects with no disease, $\mathrm{p}<0.05$. immunohistochemistry, whereas the sense control probe showed no signal (Figure 1C).

To test whether CFTR deficiency is directly responsible for Bcl-2 expression, primary airway epithelial cells from three subjects with no lung disease and three subjects with $\mathrm{CF}$ were maintained in culture on an air-liquid interface and allowed to differentiate into columnar cells. Cells from control subjects and subjects with $\mathrm{CF}$ showed a time-dependent increase in goblet cells per millimeter of BL over 7, 14, and 21 days (Figure 1D). Significant differences in goblet mucous cells/millimeter of basal lamina were observed in the cultures obtained from three normal subjects and three subjects with CF at 7 days, when cells had just reached confluence. No differences were found at 14 and 21 days, when cells had formed a differentiated columnar epithe- lium. This finding shows that the change in the number of mucous cells/millimeter of BL from 7 to 14 days was greater for normal subjects compared with those with CF. No differences were observed in the percentage of Bcl-2-positive cells in control and CF samples (data not shown).

\section{Resolution of LPS-induced GCM in Rats}

The number of cells that contain mucosubstances increased from an average of 15 to an average of 76 cells $/ \mathrm{mm}$ BL from 2 to 4 days and decreased to approximately 43 cells $/ \mathrm{mm}$ BL at 8 days after instillation. The mucous cell numbers decreased to background levels at 12 days to the numbers found in rats instilled with saline (8-20 cells/mm BL) throughout the 16 days after instillation (Figure 2A). The morphology of airway epithelial 

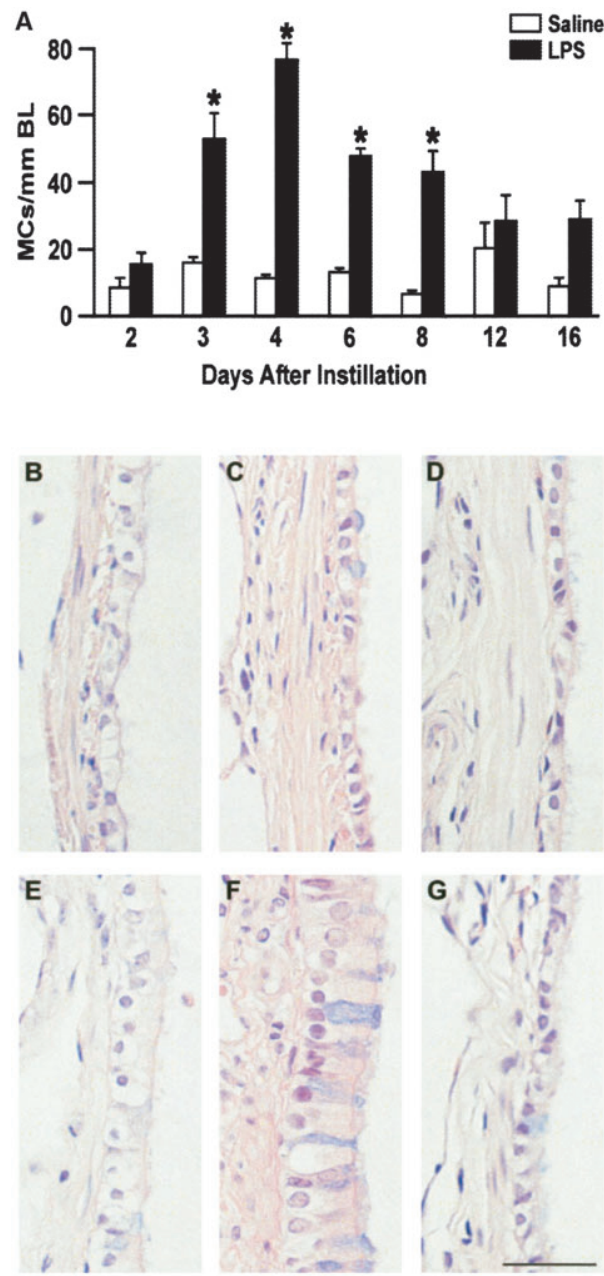

Figure 2. $(A)$ The number of MCs per millimeter of $B L$ in saline- and LPS-instilled rats. The number of AB/periodic acid-Schiff (PAS)-positive epithelial cells were enumerated and normalized to millimeter length of BL. Values are group means $\pm \mathrm{SEM} ; \mathrm{n}=5$ rats/group. *Significantly different from saline-instilled control animals, $p<0.05$. (B-G) Photomicrographs of airway epithelia from rats instilled with saline $(B-D)$ or LPS $(E-G)$. Tissue sections were stained with hematoxylin-eosin and $A B$; photomicrographs are representative for $2(B$ and $E), 3(C$ and $F)$, and $12(D$ and $G)$ days after instillation. Bar represents $20 \mu \mathrm{m}$.

cells remained cuboidal in saline-instilled rats throughout the 16 days after instillation (Figures 2B-2D). In LPS-instilled rats, the thickness of the epithelium was already increased at 2 days, reached maximum $(\sim 21 \pm 1.4 \mu \mathrm{m})$ at 3 to 4 days, and returned to the original thickness $(9.2 \pm 0.001 \mu \mathrm{m})$ at 12 to 16 days after instillation (Figures 2E-2G).

Accompanying this GCM, a significant increase in Bcl-2positive mucous cells (20-30\% in LPS rats compared with 3-7\% in saline rats) was found at 2, 3, 4, and 6 days after instillation in LPS-instilled rats (Figure 3A). No differences between salineand LPS-instilled rats were evident 8 to 16 days after instillation. Although the granular staining of Bcl-2 is visible in Alcian bluepositive cells at 2 to 6 days, very few cells were immunopositive at 12 days after instillation (Figures 3B-3D).

\section{Bcl-2 Sustains LPS-induced GCM in Nasal Epithelia}

The direct role of Bcl-2 in sustaining metaplastic mucous cells in airway epithelia was investigated by downregulating its ex-
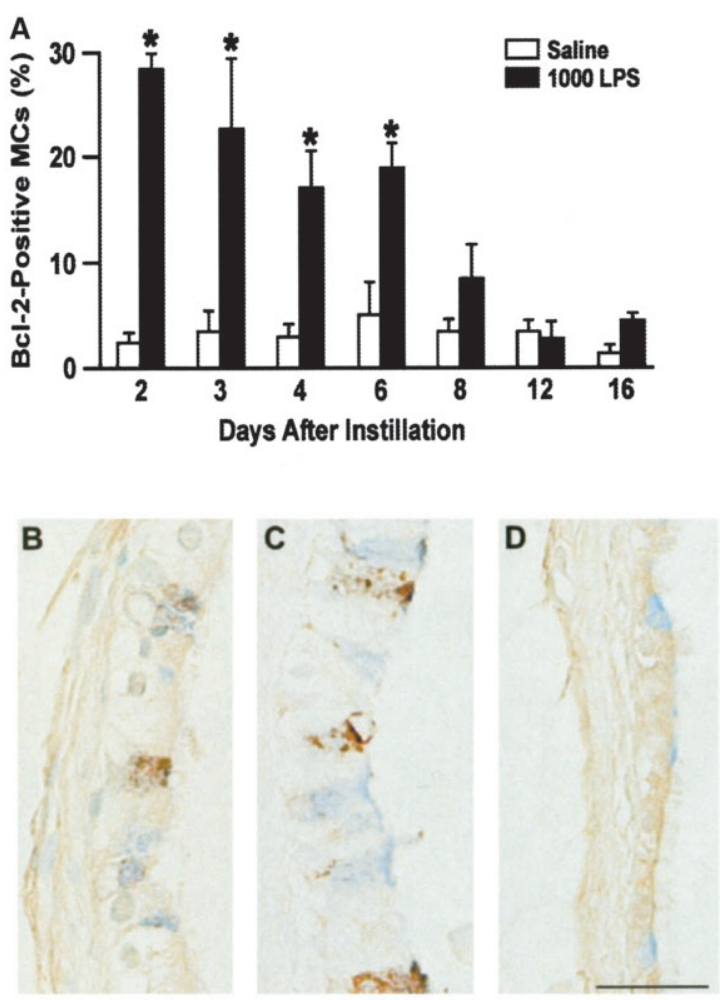

Figure 3. (A) Expression of $\mathrm{Bcl}-2$ at various time points after LPS instillation. The percentage of $\mathrm{BCl}-2-$ positive MCs in rats instilled with saline or $1000 \mu \mathrm{g}$ LPS from 2 to 16 days after instillation. The tissue sections were immunostained for $\mathrm{BCl}-2$ and counterstained with $A B$ to identify denoting the mucus-producing cells. At least $400 \mathrm{MCs}$ were counted in each rat to determine the percentage of Bcl-2-positive MCs. Similar immunostaining was observed with two different antibodies (BD-Pharmingen and Santa $\mathrm{Cruz}$ ) to $\mathrm{BCl}-2$. * Significantly different from salineinstilled control animals, $p<0.05$. ( $B-D)$ Representative photomicrographs show that $\mathrm{BCl}-2$ is expressed in mucus-producing cells following LPS instillation. Tissue sections from the left lung at generation 5 from rats at $2(B), 3(C)$, and $12(D)$ days after instillation were immunostained for $\mathrm{BCl}-2$ and $\mathrm{AB}$ to identify mucus-containing cells. $\mathrm{Bcl}-2$ was detected with diaminobenzidine and shows brown. Bar represents $20 \mu \mathrm{m}$.

pression with ASODNs in cultured nasal explants. We screened 25 ASODNs for inhibition of GCM and Bcl-2 mRNA expression in the organ culture system where GCM can be induced by treating the distal midseptum from the rat nose with LPS (14). This screening identified four ASODNs that significantly reduced LPS-induced mucous cells in nasal explant cultures (Figure 4A). Two of four ASODNs (64 and 83) showed a significant reduction of GCM in repeat experiments and were therefore selected for testing their efficacy by treating nasal explant cultures at 3-, 30-, 60-, or 90- $\mu \mathrm{M}$ concentrations. ASODN 83 effectively reduced GCM, even at $3-\mu \mathrm{M}$ concentrations, whereas ASODN 64 was most effective at the $90-\mu \mathrm{M}$ concentration (Figure 4B). In situ hybridization for Bcl-2 mRNA showed a marked reduction of the mRNA in nasal explants treated with ASODN 64 (Figure 4C). Similar results were observed for ASODN 83 (data not shown).

We further tested whether LPS-induced GCM in distal nasal midsepta can be reduced by injection of rats with ASODNs to the Bcl-2 mRNA. Rats were injected intraperitoneally with saline, control ODN, or ASODN 64 twice per day at $5 \mathrm{mg} / \mathrm{kg}$ for 7 days before LPS instillation and 2 days after instillation. The amount 

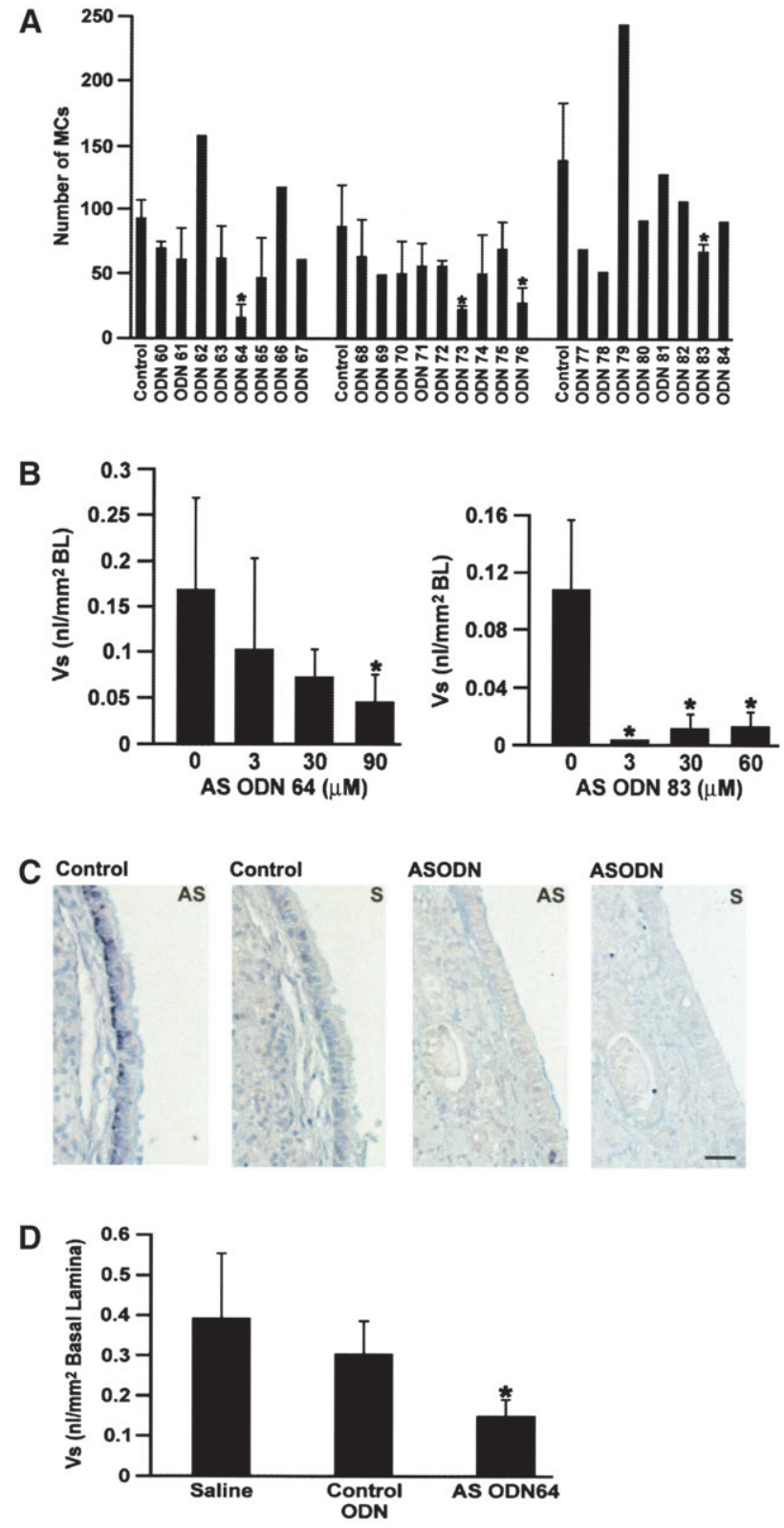

of stored mucosubstances in respiratory epithelia of distal nasal septa was significantly reduced in rats injected with ASODN 64 compared with those injected with control ODN or saline as control (Figure 4D).

\section{BCl-2 Sustains GCM in Pulmonary Airways}

The effect of downregulating Bcl-2 expression on LPS-induced GCM in pulmonary airways was examined by injecting rats intraperitoneally with ASODNs 83 and 64 every day for a total of 9 days starting 7 days before intratracheal instillation with $1 \mathrm{mg}$ LPS. GCM was assessed at 3 days after LPS instillation in the airway epithelium at generation 5. The total cell number per millimeter of BL (Figure 5A), the number of mucous cells per millimeter of BL, and the amount of stored mucosubstances (Figure 5B) in the airways of rats instilled with LPS were significantly reduced by ASODN 64. Furthermore, the percentage of Bcl-2-positive mucous cells was reduced significantly by ASODN 64 (Figure 6A). ASODN 83 caused a minor, statistically nonsignificant reduction of total epithelial cell number and mu-
Figure 4. (A) Four of 25 antisense oligonucleotides (ASODNs) significantly reduced the number of MCs in explant cultures. Organ cultures from rat distal nasal midsepta were placed in culture on transwell membranes in an air-liquid interface and treated with $100 \mu \mathrm{g} / \mathrm{ml}$ LPS for 24 hours and treated with $30 \mu \mathrm{M}$ ASODNs to Bcl-2 mRNA throughout the 3-day culture period or were left untreated as control. Explant cultures were fixed 2 days later in zinc formalin, histochemically stained with $A B / P A S$ to detect acidic and neutral intraepithelial mucosubstances stored in the epithelial cells, and analyzed for the number of MCs. The 25 ASODNs were tested in three separate experiments (8-9 ASODNs with an untreated group as control in each experiment). Error bars represent group mean values \pm SEM ( $n=4$ explant cultures/experimental group). *Significantly different from untreated control explant cultures, $p<0.05$. (B) A dose-dependent effect of ASODNs 64 and 83 on stored mucous substances in the nasal explant cultures. Nasal explants were placed in culture on transwell membranes, exposed to $100 \mu \mathrm{g}$ LPS for 24 hours, and treated with the respective ASODNs at 3-, 30-, 60-, or 90- $\mathrm{MM}$ concentrations throughout the culture period. Tissues were processed 2 days after LPS treatment, and volume density (Vs) of stored mucosubstances in the surface epithelium was determined by morphometry. ASODN 83 shows a significant reduction at $3-\mu \mathrm{M}$ concentration. ASODN 64 shows a significant reduction only at $90-\mu \mathrm{M}$ concentration. Bars represent group mean values \pm SEM ( $n=4$ explant cultures/group). * Significantly different from untreated controls, $\mathrm{p}<0.05$. (C) In situ hybridization of control ODN- or ASODN 64-treated nasal septa with antisense probe to $\mathrm{BCl}-2$ (AS) or with the sense cRNA probe as control (S). Bar represents $15 \mu \mathrm{m}$. (D) ASODN 64 reduces the LPS-induced goblet cell metaplasia (GCM) in the distal nasal septum in in vivo rats. Rats were injected intraperitoneally with saline control ODN or ASODN 64 mornings and evenings with $5 \mathrm{mg} / \mathrm{kg}$ for a total of $10 \mathrm{mg} / \mathrm{kg} /$ day for 9 consecutive days. On Day 7, all rats received an intranasal instillation (100 $\mu \mathrm{l} /$ naris) of a 1 -mg LPS solution in saline. Two days after LPS instillation, rats were killed, and GCM in the epithelium of the distal nasal septum was quantified by morphometry after histochemical stain with $A B / P A S$. Bars represent group mean values \pm SEM $(n=6$ rats/experimental group). *Significantly different from distal septal epithelium of rats injected with saline or control ODN, $\mathrm{p}<0.05$. cous cells per millimeter of BL and of amount in intraepithelial stored mucosubstances. ASODN 84, which was not effective in organ culture experiments, showed similar numbers of total epithelial cells and mucous cells per millimeter of BL and similar percentages of Bcl-2-positive mucous compared with rats injected with control ODN (data not shown). No differences in inflammation were observed in lung tissues from control- or ASODN-treated rats. However, the epithelial thickness was reduced when rats were injected with ASODNs 83 and 64, but not with control ODN (Figure 5D).

The effect of treatment with control ODN or ASODN 83 and 64 on the levels of Bcl-2, Bcl- $\mathrm{x}_{\mathrm{L}}, \mathrm{Bax}$, and Bak, the major regulators of this protein family, was tested. The percentage of Bcl-2-positive mucous cells was more efficiently reduced by ASODN 64 compared with control ODN or ASODN 83 (Figures 6A and 6B). The protein levels of Bcl- $\mathrm{x}_{\mathrm{L}}, \mathrm{Bax}$, and Bak were tested in extracts prepared from the right lungs of three representative rats from each treatment group. Interestingly, not only $\mathrm{Bcl}-2$ but also Bcl- $\mathrm{x}_{\mathrm{L}}$ levels were reduced by treatment with ASODNs 83 and 

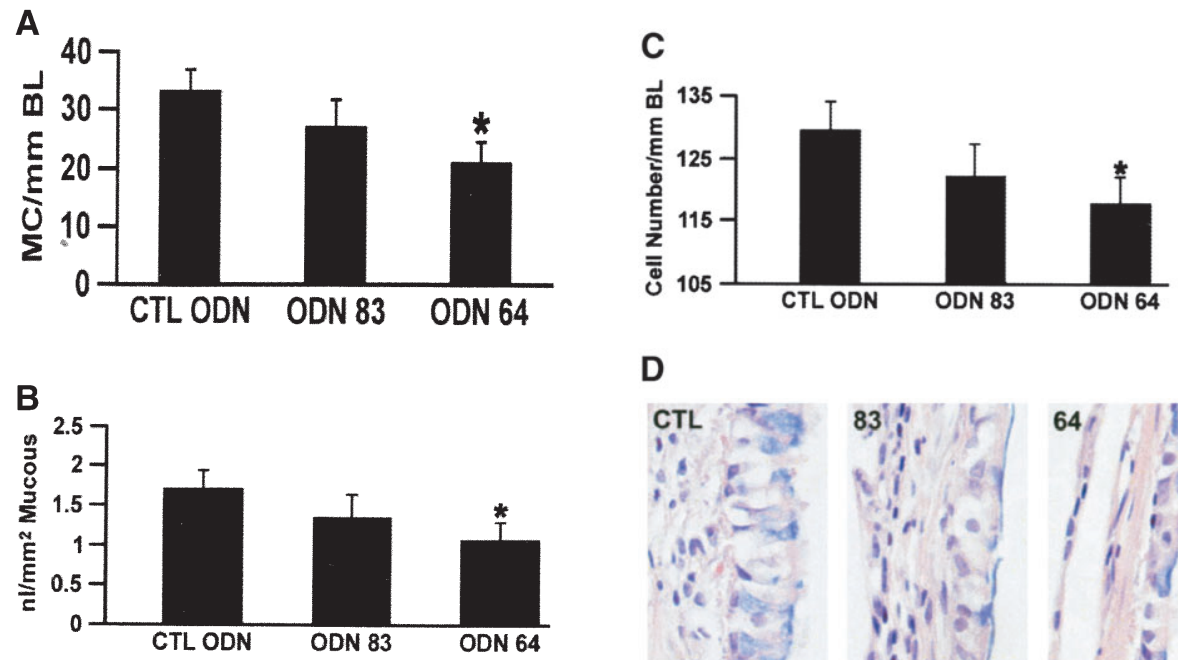

D

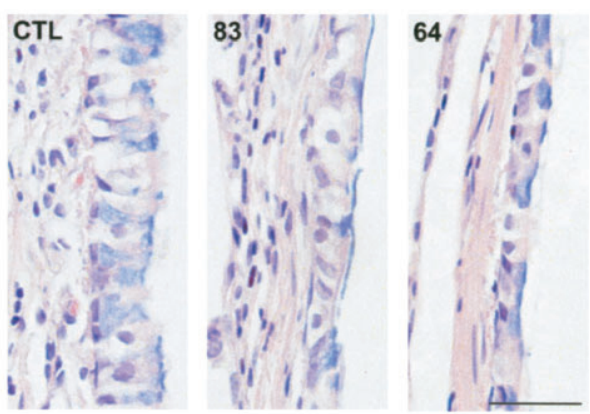

Figure 5. ASODN reduces LPS-induced GCM, the Vs, and the number of epithelial cells per millimeter of BL in pulmonary airways in in vivo rats. Rats were injected intraperitoneally with control (CTL) ODN, ASODN 83, or ASODN 64 twice a day for 10 consecutive days. On Day 7, all rats received an intratracheal instillation of $1 \mathrm{mg}$ LPS in $500 \mu \mathrm{l}$. Three days after LPS instillation, rats were killed, and the numbers of MCs per millimeter of BL ( $A$ ) and the amount of stored mucosubstances $(B)$ in the epithelium of airway generation 5 were quantified by morphometry after histochemical stain with $A B / P A S$. Adjacent sections were stained with hamatoxylin-eosin followed by $A B$ for quantification of the total numbers of cells per millimeter of $\mathrm{BL}(C)$. Bars represent group mean values \pm SEM ( $\mathrm{n}=6$ rats/experimental group). *Significantly different than distal septal epithelium of rats injected with control ODN, $\mathrm{p}<0.05$. (D) Photomicrographs of axial airways at generation 5 in the left lung lobe of rats injected with control ODN, ASODN 83, and ASODN 64. Tissue sections were stained with hematoxylin-eosin and counterstained with AB. Bar represents $30 \mu \mathrm{m}$.

64 compared with control ODN (Figure 6C). However, the levels of the proapoptotic proteins Bax and Bak were not affected by the ASODN treatments (Figure 6C).

\section{Sustained GCM in Bcl-2 Transgenic Mice}

Transgenic mice with Bcl-2 under the control of the MT1 promoter, which is inducible by zinc water, were used to further establish the role of Bcl-2 expression in sustaining LPS-induced mucous cell metaplasia. We and others had previously shown that $\mathrm{C} 56 \mathrm{Bl} / 6$ mice instilled with LPS display $\operatorname{GCM}(13,23)$. Bcl-2 expression was 10 -fold greater in transgenic compared with wildtype littermates 8 days after LPS instillation (Figure 7A), and goblet cells in transgenic but not wild-type mice showed Bcl-2 positivity (Figure 7B). Furthermore, GCM in wild-type mice was
A

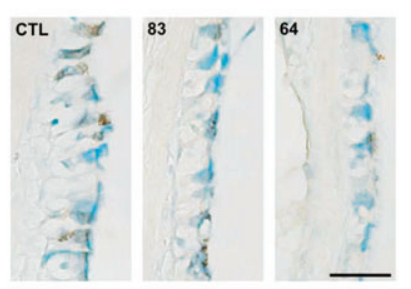

B

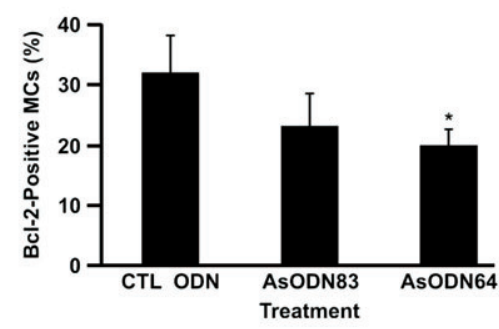

C
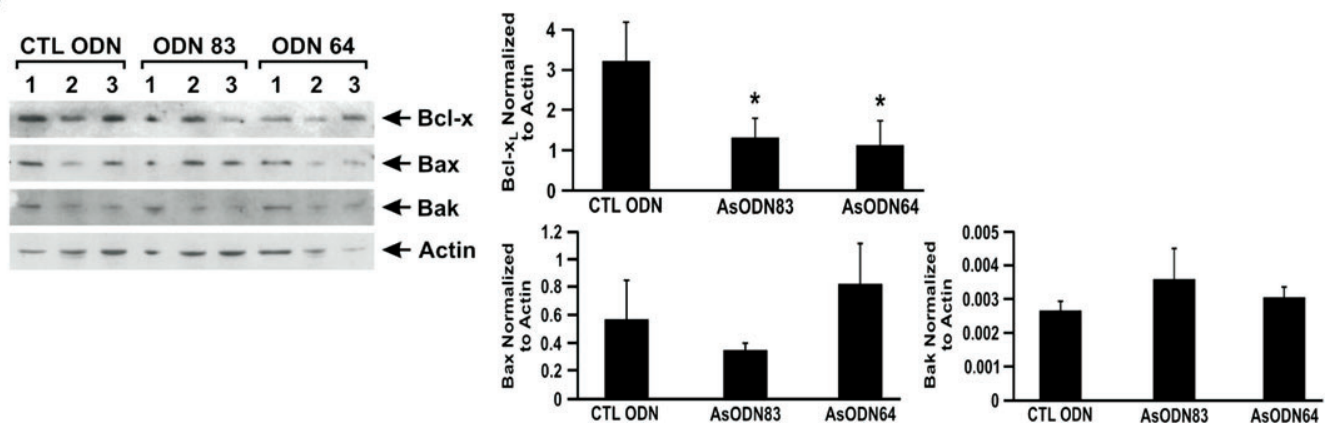

Figure 6. $\mathrm{Bcl}-2$ protein levels are reduced in rats injected with ASODN 64 compared with control (CTL) ODN-injected animals. Bar represents $30 \mu \mathrm{m}$. $(A, B)$ The percentage of $\mathrm{BCl}-2$ positive MCs was reduced in rats injected with ASODNs 83 and 64 compared with those injected with control ODN. Bars represent group mean values \pm SEM ( $n=6$ rats/experimental group). *Significantly different from control ODN. (C) Densitometric quantification of $\mathrm{BCl}-\mathrm{xL}$, Bax, and Bak after normalizing to actin in proteins extracted from three rat lungs each injected with control ODN and ASODNs 83 and 64. 
A

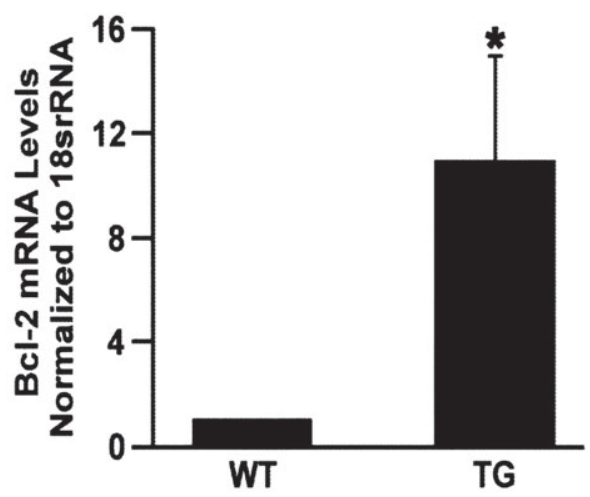

B

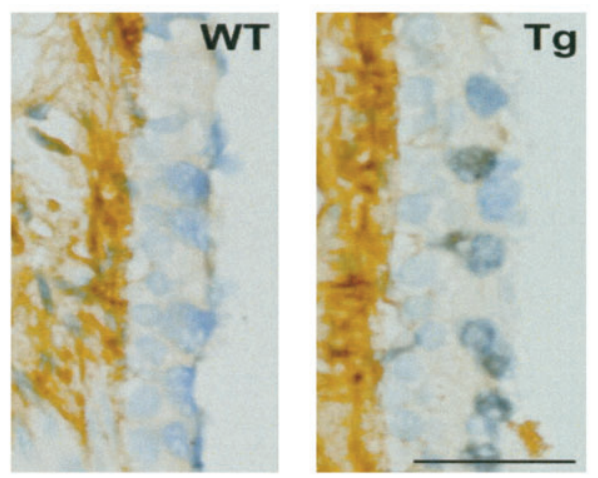

C

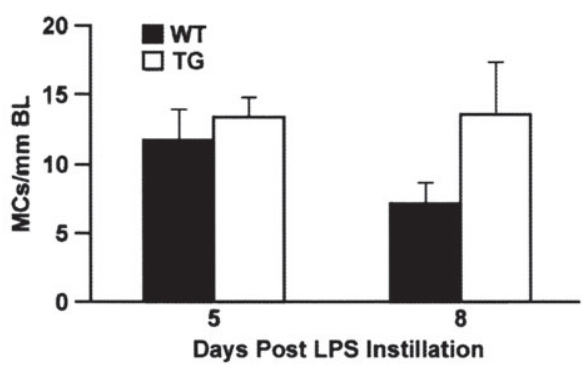

Figure 7. Sustained $\mathrm{Bcl}-2$ expression in transgenic mice sustains LPSinduced GCM. Both wild-type (WT) and human Bcl-2 transgenic (TG) mice with the $\mathrm{BCl}-2$ transgene under the control of the mouse MT1 promoter on a $\mathrm{C} 57 \mathrm{Bl} / 6$ background were maintained on $25 \mathrm{mM}$ zinc sulfate drinking water to induce transgene expression. Mice were instilled with LPS on 3 consecutive days with $180 \mu \mathrm{g}$ in $50 \mu \mathrm{L}$ saline, a protocol previously shown to induce maximum GCM in C57BI/6 mice. $(A)$ Increased expression of $\mathrm{BCl}-2$ was detected 8 days after LPS instillation in lungs of TG mice that express a zinc-inducible $\mathrm{BCl}-2$ transgene in airway epithelia compared with WT mice when they were maintained on water with zinc sulfate. Bars represent group mean values \pm SEM ( $n=3$ /group). *Significantly different from WT, $p<0.05$. (B) Representative photomicrographs of Bcl-2 immunostaining cells in WT and TC ( $\mathrm{Tg})$ mice at 8 days after LPS instillation. Bar represents $20 \mu \mathrm{m}$. (C) GCM was quantified in these mice over a period of 5 and 8 days after LPS instillation. GCM was similar in both WT and TG mice at 5 days after LPS instillation. However, at 8 days, GCM was decreased in WT but sustained in TG mice. decreased at 8 days after instillation, but remained elevated in Bcl-2 transgenic mice (Figure 7C).

\section{DISCUSSION}

The present study shows that Bcl-2 is present in airway mucous cells of subjects with CF and that LPS-induced epithelial proliferation and GCM is transiently sustained by the expression of this antiapoptotic protein.

Interestingly, Bcl-2 expression was significantly reduced (as shown by the percentage of Bcl-2-positive mucous cells and by Western blot analyses) but not completely suppressed by the ASODN treatment. This finding suggests that it is not crucial to completely inhibit Bcl-2 expression to cause the reduction of epithelial cell numbers and GCM and that proapoptotic signals initiate the proapoptotic cascade once $\mathrm{Bcl}-2$ and $\mathrm{Bcl}-\mathrm{x}_{\mathrm{L}}$ are reduced to a certain threshold level. It is unclear why ASODN 64 was not as effective as ASODN 83 in downregulating GCM in organ culture but was more effective when injected in rats instilled with LPS. The presence of a large amount of inflammatory mediators in in vivo rats may result in differences in the stability of these ASODNs and contribute to this observed difference. Bcl-2 homology region-3-only subfamily members are known to induce apoptosis by association with antiapoptotic Bcl-2 family members or by stimulating other apoptosis-promoting family members $(7,9,24,25)$.

The reduction of $\mathrm{Bcl}-2$ and $\mathrm{Bcl}-\mathrm{x}_{\mathrm{L}}$, the major antiapoptotic proteins, may have allowed the proapoptotic proteins Bax and Bak to initiate the cell-death process. Although epithelial cells undergoing cell death are not presented in this study, terminal deoxy-nucleotidyl transferase-mediated dUTP nick end labeling (TUNEL-)-positive cells have been detected at the early times after LPS instillation in mice (26). Furthermore, we have reported that the resolution of allergen-induced GCM is associated with the presence of TUNEL-positive cells and activated caspase 3 (27). Ongoing studies will characterize the cell death by which epithelial cells are removed from the epithelium.

The reason why $\mathrm{Bcl}-\mathrm{x}_{\mathrm{L}}$ levels were reduced in lungs when rats were injected with ASODNs to Bcl-2 is not clear. The homology of Bcl-2 and Bcl- $x_{\mathrm{L}}$ mRNAs in the regions where ASODNs 83 and 64 are localized is $50 \%$. This level of homology may be sufficient to bind and downregulate $\mathrm{Bcl}-\mathrm{x}_{\mathrm{L}} \mathrm{mRNA}$ because of similarity in the tertiary structures between these mRNAs. Consistent with our findings, a Bcl-2/Bcl-xL bispecific ASODN inhibits the expression of $\mathrm{Bcl}-2$ and $\mathrm{Bcl}-\mathrm{xL}$ in a representative breast carcinoma cell line and inhibits the growth and induces death in cell lines from lung, breast, colorectal, and prostate carcinomas in vitro (28).

The reduction of Bcl-2 expression with ASODNs decreased the total epithelial cell number and GCM, thereby directly linking Bcl-2 expression to GCM. Because the ASODNs were administered before LPS instillation, it is possible that the reduction of Bcl-2 expression affected the inflammation-induced epithelial cell proliferation. However, our previous studies demonstrate that approximately half of the Bcl-2-positive cells had undergone a cell cycle division whereas the other half had not incorporated $\mathrm{BrdU}$ and were therefore derived from preexisting epithelial cells (2). These studies suggest that Bcl-2 expression is not involved in regulating cell cycle in this system. Further support for the role of Bcl-2 in sustaining GCM was established by timecourse experiments demonstrating that the reduction of $\mathrm{Bcl}-2$ expression to background levels occurs before the resolution of GCM (5). In addition, the decrease in Bcl-2-positive mucous cells seen after injection of rats with bezafibrate was associated with significant reduction of LPS-induced mucous cells per millimeter of BL (12). These observations together with the known 
antiapoptotic function of Bcl-2 $(29,30)$ confirm that Bcl-2 sustains the lifespan of mucous cells after inflammatory responses.

The reduction of LPS-induced GCM in distal septa as well as pulmonary airways of rats injected with ASODNs to the Bcl-2 mRNA suggests that the processes involved in the resolution of GCM in epithelia lining the nasal midsepta and the pulmonary airways are similar. Our previous studies have established that $\mathrm{Bcl}-2$ is expressed in ozone- or LPS-induced GCM, both in nasal and pulmonary airways $(4,5)$. Because the distal region of the nasal septum and the main axial pulmonary airways are lined by a tall columnar respiratory epithelium with primarily seroustype (not mucous) secretory cells $(31,32)$, similar regulation of the resolution process of LPS-induced GCM in these epithelia is not surprising. These results suggest, therefore, that targeting $\mathrm{Bcl}-2$ expression with ASODN may be useful to reduce GCM and airway obstruction in humans with bronchopneumonia or rhinitis.

In the rat, the proximal midseptum is lined by a mucociliary epithelium with endogenous mucous cells. Exposure to ozone does not change the numbers of mucous cells in this epithelium but induces GCM in epithelia that line the lateral wall and the naso- and maxilloturbinates (33). Interestingly, although the percentage of Bcl-2-positive cells remains low in the proximal midseptum, up to $50 \%$ of mucous cells express Bcl-2 where metaplastic changes occur (4). Together with our current finding that Bcl-2 sustains the life span of metaplastic mucous cells, we conclude that Bcl-2 is expressed only in epithelia where mucous cell numbers have to be regulated. In addition, the total number of epithelial cells per millimeter of BL that was reduced in rats injected with ASODN 64 was similar to the reduction in the number of mucous cells per millimeter of BL, suggesting that the epithelium removes primarily mucous cells to restore the original number of epithelial cells. Therefore, targeting Bcl-2 may primarily reduce metaplastic cells without affecting endogenous mucous cells, which makes this approach valuable and relevant for therapies in chronic diseases.

The presence of $\mathrm{Bcl}-2$ in mucous cells from subjects with $\mathrm{CF}$ indicates that this protein may be a useful target for reducing mucous secretions. Our studies with cells from subjects with $\mathrm{CF}$ and control subjects show that cells from subjects with $\mathrm{CF}$ are capable of differentiating to mucous cells, even at the time when they reach confluence without the formation of a columnar epithelium. The fact that cells from subjects with $\mathrm{CF}$ do not have more mucus-producing epithelial cells compared with control subjects at confluence indicates a blunted capacity for in vitro differentiation of $\mathrm{CF}$ cells to a mucus-producing phenotype. Deficiency in $\mathrm{CF}$ is not directly responsible for $\mathrm{Bcl}-2$ expression. Therefore, it is likely that the presence of bacterial infections in $\mathrm{CF}$ (34) may be causing sustained Bcl-2 expression. It is also possible that dysregulated expression of $\mathrm{Bcl}-2$ or the presence of inflammatory mediators sustain activation of Bcl-2 promoter, causing sustained GCM and airway obstruction. This hypothesis is supported by our finding that the sustained expression of $\mathrm{Bcl}-2$ in transgenic mice, where the metallothionein promoter is activated with zinc water, prolongs the presence of GCM compared with wild-type mice.

Increased expression of $\mathrm{Bcl}-2$ after inflammatory responses may be crucial to sustain a transient increase of mucous cell numbers, for the epithelium to have sufficient mucus to protect injury by further insults. However, dysregulated expression of Bcl-2 may sustain GCM to cause disease. Studies have demonstrated that, in patients with $\mathrm{CF}$ and in horses with reactive airway obstruction, mucous secretions accumulate in airways and cause obstruction $(35,36)$. Bcl-2 is also expressed in approximately $50 \%$ of mucous cells in horses with reactive airway obstruction (Y.T., personal observation). Thus, our studies showing Bcl-2 expression in mice, rats, horses, and humans suggest that resolution of GCM by this mechanism is conserved among species and support the hypothesis that targeting Bcl-2 for downregulation may be useful to reduce mucous cell numbers and alleviate mucous secretions.

Conflict of Interest Statement: J.F.H. does not have a financial relationship with a commercial entity that has an interest in the subject of this manuscript; M.J.F. does not have a financial relationship with a commercial entity that has an interest in the subject of this manuscript; J.R.H. does not have a financial relationship with a commercial entity that has an interest in the subject of this manuscript; B.P.M. does not have a financial relationship with a commercial entity that has an interest in the subject of this manuscript; S.H.R. has consulted for Vertex Pharmaceuticals, Inc., and Novartis Institutes for BioMedical Research, Inc., on matters not directly related to the material in this article and has received an honorarium for a lecture from Vertex Pharmaceuticals, Inc.; J.R.H. does not have a financial relationship with a commercial entity that has an interest in the subject of this manuscript; Y.T. does not have a financial relationship with a commercial entity that has an interest in the subject of this manuscript.

Acknowledgment: The authors thank Ms. Yoneko Knighton for preparing tissue samples for light microscopic analyses. They thank Mr. Nick Johnson for technical assistance and Mr. Jay Aden for support with statistical analyses.

\section{References}

1. Wells AB. The kinetics of cell proliferation in the tracheobronchial epithelia of rats with and without chronic respiratory disease. Cell Tissue Kinet 1970;3:185-206.

2. Tesfaigzi Y, Harris JF, Hotchkiss JA, Harkema JR. DNA synthesis and Bcl-2 expression during the development of mucous cell metaplasia in airway epithelium of rats exposed to LPS. Am J Physiol Lung Cell Mol Physiol 2004;286:L268-L274.

3. Harkema J, Hotchkiss J, Harmsen A, Henderson R. In vivo effects of transient neutrophil influx on nasal respiratory epithelial mucosubstances: quantitative histochemistry. Am J Pathol 1988;130:605-615.

4. Tesfaigzi J, Hotchkiss JA, Harkema JR. Expression of Bcl-2 during mucous cell metaplasia and remodeling in F344/N rats. Am J Respir Cell Mol Biol 1998;18:794-799.

5. Tesfaigzi Y, Fischer MJ, Martin AJ, Seagrave J. Bcl-2 in LPS- and allergeninduced hyperplastic mucous cells in airway epithelia of Brown Norway rats. Am J Physiol Lung Cell Mol Physiol 2000;279:L1210-L1217.

6. Tesfaigzi Y, Fischer MJ, Green FHY, De Sanctis GT, Wilder JA. Bax is crucial for IFNg-induced resolution of allergen-induced mucous cell metaplasia. J Immunol 2002;169:5919-5925.

7. Adams JM, Cory S. The Bcl-2 protein family: arbiters of cell survival. Science 1998;281:1322-1326.

8. Thornberry NA, Lazebnik Y. Caspases: enemies within. Science 1998; 281:1312-1316.

9. Wei MC, Zong WX, Cheng EH, Lindsten T, Panoutsakopoulou V, Ross AJ, Roth KA, MacGregor GR, Thompson CB, Korsmeyer SJ. Proapoptotic BAX and BAK: a requisite gateway to mitochondrial dysfunction and death. Science 2001;292:727-730.

10. Strasser A, O'Connor L, Dixit VM. Apoptosis signaling. Annu Rev Biochem 2000;69:217-245.

11. Tesfaigzi Y, Harris JF, Hotchkiss JA, Robinson EN, Monia BP, Randell $\mathrm{SH}$, Harkema JR. Bcl-2 is expressed in mucous cells of chronic airway diseases and sustains LPS-induced mucous cell metaplasia in nasal and pulmonary epithelia [abstract]. Am J Respir Crit Care Med 2004; 169(Suppl):A537.

12. Foster JE, Gott K, Schuyler MR, Kozak W, Tesfaigzi Y. LPS-induced neutrophilic inflammation and Bcl-2 expression in metaplastic mucous cells. Am J Physiol Lung Cell Mol Physiol 2003;285:L405-L414.

13. Tesfaigzi Y, Rudolph K, Fischer MJ, Conn CA. Bcl-2 mediates sexspecific differences in recovery of mice from LPS-induced signs of sickness independent of IL-6. J Appl Physiol 2001;91:2182-2189.

14. Fanucchi MV, Harkema JR, Plopper CG, Hotchkiss JA. In vitro culture of microdissected rat nasal airway tissues. Am J Respir Cell Mol Biol 1999;20:1274-1285.

15. Monia BP, Johnston JF, Geiger T, Muller M, Fabbro D. Antitumor activity of a phosphorothioate antisense oligodeoxynucleotide targeted against C-raf kinase. Nat Med 1996;2:668-675.

16. Harkema JR, Hotchkiss JA. In vivo effects of endotoxin on intraepithelial mucosubstances in rat pulmonary airways: quantitative histochemistry. Am J Pathol 1992;141:307-317.

17. El-Zimaity HM, Ota H, Scott S, Killen DE, Graham DY. A new triple stain for Helicobacter pylori suitable for the autostainer: carbol fuchsin/Alcian blue/hematoxylin-eosin. Arch Pathol Lab Med 1998;122: $732-736$. 
18. Spicer SS, Chakrin LW, Wardell JR Jr, Kendrick W. Histochemistry of mucosubstances in the canine and human respiratory tract. Lab Invest 1971;25:483-490.

19. Harkema JR, Hotchkiss JA. In vivo effects of endotoxin on nasal epithelial mucosubstances: quantitative histochemistry. Exp Lung Res 1991; 17:743-761.

20. Tesfaigzi Y, Wright PS, Belinsky SA. SPRR1B overexpression enhances entry of cells into the G0 phase of the cell cycle. Am J Physiol Lung Cell Mol Physiol 2003;285:L889-L898.

21. Heid CA, Stevens J, Livak KJ, Williams PM. Real time quantitative PCR. Genome Res 1996;6:986-994.

22. Tesfaigzi J, Smith-Harrison W, Carlson DM. A simple method for reusing Western blots on PVDF membranes. Biotechniques 1994;17:268-269.

23. Yanagihara K, Seki M, Cheng PW. Lipopolysaccharide induces mucus cell metaplasia in mouse lung. Am J Respir Cell Mol Biol 2001;24: 66-73.

24. Puthalakath H, Strasser A. Keeping killers on a tight leash: transcriptional and post-translational control of the pro-apoptotic activity of $\mathrm{BH} 3-$ only proteins. Cell Death Differ 2002;9:505-512.

25. Villunger A, Michalak EM, Coultas L, Mullauer F, Bock G, Ausserlechner MJ, Adams JM, Strasser A. p53- and drug-induced apoptotic responses mediated by $\mathrm{BH} 3$-only proteins puma and noxa. Science 2003;302:1036-1038.

26. Vernooy JH, Dentener MA, van Suylen RJ, Buurman WA, Wouters EF. Intratracheal instillation of lipopolysaccharide in mice induces apoptosis in bronchial epithelial cells: no role for tumor necrosis factor-alpha and infiltrating neutrophils. Am J Respir Cell Mol Biol 2001;24:569-576.

27. Shi ZQ, Fischer MJ, De Sanctis GT, Schuyler M, Tesfaigzi Y. IFNg but not Fas mediates reduction of allergen-induced mucous cell metaplasia by inducing apoptosis. J Immunol 2002;168:4764-4771.

28. Gautschi O, Tschopp S, Olie RA, Leech SH, Simoes-Wust AP, Ziegler A, Baumann B, Odermatt B, Hall J, Stahel RA, et al. Activity of a novel bcl-2/bcl-xL-bispecific antisense oligonucleotide against tumors of diverse histologic origins. J Natl Cancer Inst 2001;93:463-471.

29. Zong WX, Lindsten T, Ross AJ, MacGregor GR, Thompson CB. BH3only proteins that bind pro-survival $\mathrm{Bcl}-2$ family members fail to induce apoptosis in the absence of Bax and Bak. Genes Dev 2001;15:14811486.

30. Green DR, Reed JC. Mitochondria and apoptosis. Science 1998;281:1309_ 1312.

31. Shimizu T, Shimizu S, Hattori R, Gabazza EC, Majima Y. In vivo and in vitro effects of macrolide antibiotics on mucus secretion in airway epithelial cells. Am J Respir Crit Care Med 2003;168:581-587.

32. Wagner JG, Van Dyken SJ, Wierenga JR, Hotchkiss JA, Harkema JR Ozone exposure enhances endotoxin-induced mucous cell metaplasia in rat pulmonary airways. Toxicol Sci 2003;74:437-446.

33. Wagner JG, Van Dyken SJ, Hotchkiss JA, Harkema JR. Endotoxin enhancement of ozone-induced mucous cell metaplasia is neutrophildependent in rat nasal epithelium. Toxicol Sci 2001;60:338-347.

34. Lemjabbar H, Basbaum C. Platelet-activating factor receptor and ADAM10 mediate responses to Staphylococcus aureus in epithelia cells. Nat Med 2002;8:41-46.

35. Donaldson SH, Boucher RC. Update on pathogenesis of cystic fibrosis lung disease. Curr Opin Pulm Med 2003;9:486-491.

36. Jefcoat AM, Hotchkiss JA, Gerber V, Harkema JR, Basbaum CB, Robinson NE. Persistent mucin glycoprotein alterations in equine recurrent airway obstruction. Am J Physiol Lung Cell Mol Physiol 2001;281:L704-L712. 